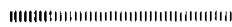

論説

WDC $669.14 .018 .291621 .7 .016 .2 .071: 548.53: 539.4 .011$

\title{
機械構造用鋼の再結晶挙動および機械的性質 に及ぼす熱間加工条件の影響
}

大宝 雄 蔵*, 高田 勝 典**

\section{Effect of Hot-Working Conditions on Recrystallization Behavior and Mechanical Properties of Machine Struc- tural Alloy Steels}

\section{Yuzo Ohtakara and Katsunori Takada}

\section{Synopsis}

After investigation of the effects of hot-working conditions on recrystallization behavior and mechanical properties of S40C, SCM 435, SCM 420 and SCM $420+\mathrm{Nb}$ steels the following results were obtained.

(1) Recrystallizations during hot-working occurred in the order of easiness S40C, SCM 435, SCM 420 and SCM $420+$ Nb steels.

(2) The value of reduction in area in the tension test can be improved by hot-working the austenite with fine grains at temperature of 750 to $800^{\circ} \mathrm{C}$ in steels but $\mathrm{S} 40 \mathrm{C}$.

(3) The result of (2) was discussed in terms of the effects of hot-working on the cooling transformation of the steels.

1. 緒

\section{言}

熱間圧延した機械構造用鋼は，伸線などの二次 加工や，切削加工，冷間鍛造などの部品加工を行 5前に，焼ならしや焼なましなとの熱処理を行ら ことが多い。熱間压延条件および圧延後の冷却条 件を最適にコントロールすれば，王延後の前記の ような熱処理を省略できるはかかりでなく，鋼材の 品質改善が期待できる。従来，制御圧延技術は非 調質型高抗張力鋼板の製造に実用化されているが

昭和 56 年 5 月 25 日 受付

*大同特殊鋼种研究開発本部中央研究所, 工博

**大同特殊鋼蛛研究開発本部中央研究所
機㑘楧造用鋼については研究が比較的少ない。筆 者らは炭素鋼，強靯鋼および肌焼鋼を取り上げ， それらの熱間加工時の再結晶挙動ならびに熱間加 工後の機械的性質に及ぼす熱間加工条件の影響に ついて調べたので報告する。

\section{2. 実跧方 法}

\section{1 供 試 材}

供試材は Table 1 に示す化学成分を有する炭素 鎆 (S40C)，強勒鋼（SCM435）および肌㜔鋼 (SCM 420 および㮹量 Nbを添加した SCM 420)の 4 種である。ビレットより切出した素材を 鍛造して熱間圧延実験用供試材とした。

\section{2 筑間压延実倹}


Table 1. Chemical composition of experimental steels.

\begin{tabular}{c|c|c|c|c|c|c|c|c|c|c}
\hline Steel & $\mathrm{C}$ & $\mathrm{Si}$ & $\mathrm{Mn}$ & $\mathrm{P}$ & $\mathrm{S}$ & $\mathrm{Cu}$ & $\mathrm{Ni}$ & $\mathrm{Cr}$ & $\mathrm{Mo}$ & $\mathrm{Nb}$ \\
\hline $\mathrm{S} \mathrm{40C}$ & 0.41 & 0.25 & 0.76 & 0.024 & 0.030 & 0.01 & 0.02 & 0.11 & - & - \\
\hline $\mathrm{S} \mathrm{CM} 435$ & 0.34 & 0.25 & 0.67 & 0.016 & 0.030 & 0.15 & 0.10 & 0.95 & 0.15 & - \\
\hline $\mathrm{S} \mathrm{CM} 420$ & 0.19 & 0.24 & 0.75 & 0.013 & 0.029 & 0.14 & 0.08 & 1.01 & 0.16 & - \\
\hline $\mathrm{S} \mathrm{CM} 420+\mathrm{N} \mathrm{b}$ & 0.18 & 0.25 & 0.78 & 0.011 & 0.014 & 0.13 & 0.05 & 1.01 & 0.15 & 0.038 \\
\hline
\end{tabular}

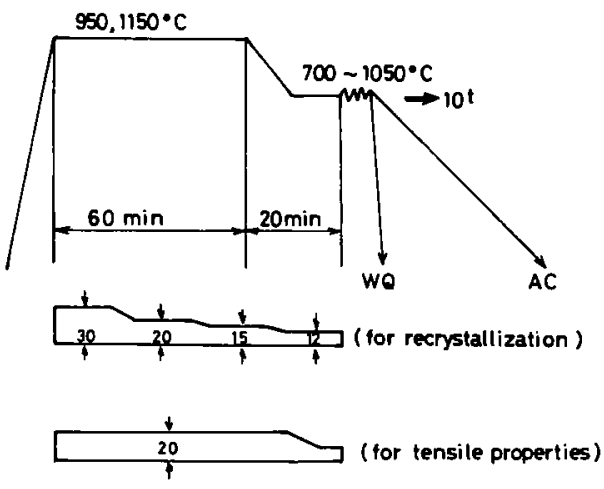

Fig. 1. Experimental method.

供試材をFig. 1 に示す階段状試験片に機械加 IL，同図に示す様式で加熱を行った後，1ハス で厚さ $10 \mathrm{~mm}$ の板に王延した。このとき 1 回の王 延で17，33，50および67\%の圧下率が試片の各部 で得られる。使用した圧延機のロール径は230 $\mathrm{mm}$ ，回転速度は $36 \mathrm{rpm}$ である。このとき車速度

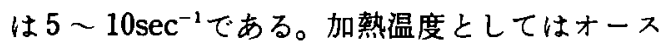
テナイトが粗大化する $1150^{\circ} \mathrm{C}$ と比較的細粒の $950^{\circ} \mathrm{C}$ の 2 水準を選んた。压延蕰度は750 $\mathrm{C}$ から $1050^{\circ} \mathrm{C}$ をでを $50^{\circ} \mathrm{C}$ 間隔にとった。

4 階段を有する試験片は压延後直ちに水冷し， ミクロ組織かっ再結晶挙動を調べた。また 1 階段 の試験は板厚 $20 \mathrm{~mm}$ から $10 \mathrm{~mm}$ へ 1 ハスで迁延 後, 空冷し圧延方向上り引張試験片を機械加工し た。またミクロ組織の観察も行い, 冷却変態組織 に及ぼす熱間加工条件の影響を調べた。なお，空 冷材の冷却速度は800 $500^{\circ} \mathrm{C}$ の間で約 $1.5^{\circ} \mathrm{C} / \mathrm{sec}$ であった。

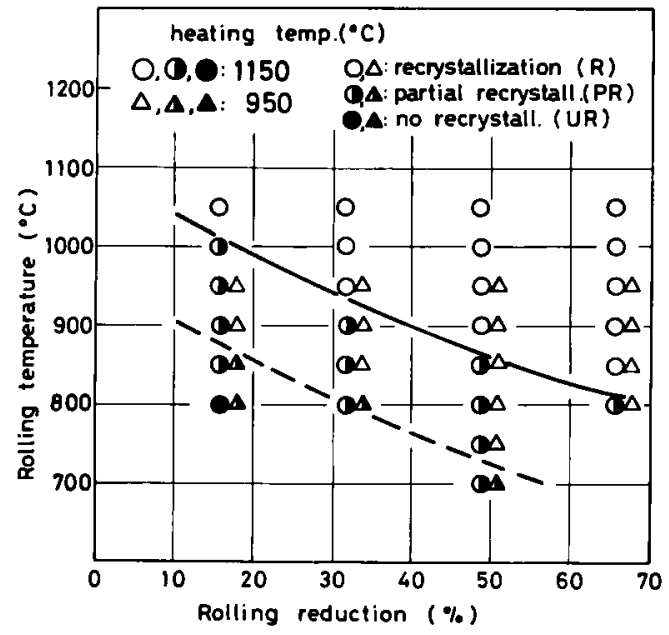

Fig. 2. Effect of rolling reduction and temperature on the recrystallization in S40C.

\section{3. 実験結果と考察}

\section{1 オーステナイトの再結晶挙㲜}

王延後急冷した試料のミク口組織を観察し，末 再結晶（UR），部分再結晶（PR）および再結 晶（R）の判定を行った。压延温度と王下率がこ れらの再結晶挙動に及ぼす影㸷を S 40 Cおよび SCM 420 を例にそれぞれ Fig. 2 およびFig. 3 に 示す。圧延前のオーステナイト粒度は S $40 \mathrm{C} の$ $1150^{\circ} \mathrm{C}$ 加熱および950 C加熱でそれぞれASTM No. 0.6 および6.8であり, SCM 420ではそれぞれ 1.8 よび6.8である。図中の曲線は再結晶と部分 再結晶の境界（R/PR境界）の圧延温度および圧 下率の条件を示す。 


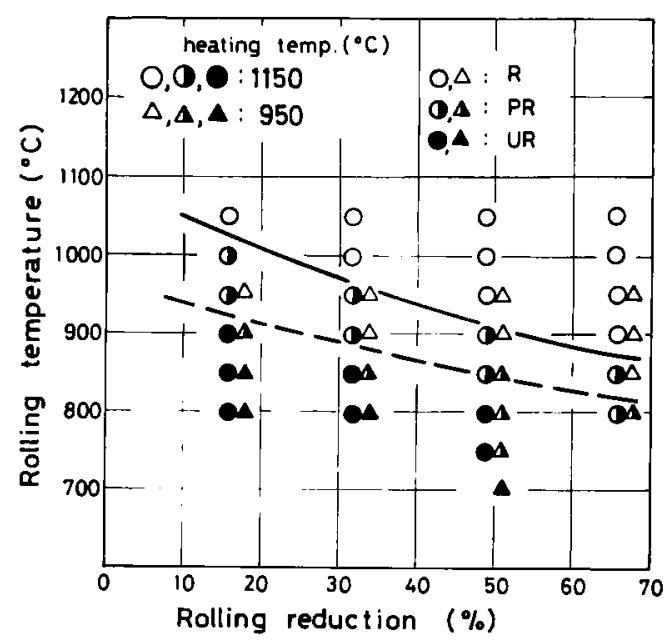

Fig. 3. Effect of rolling reduction and temperature on the recrystallization in SCM420.

$\mathrm{S} 40 \mathrm{C}$ では加熱温度が $950^{\circ} \mathrm{C}$ の場合 $\mathrm{R} / \mathrm{PR}$ 境界 線は, $1150^{\circ} \mathrm{C}$ 加熱の場合よりも約 $150^{\circ} \mathrm{C}$ 低温側にあ る。50\%王下のとき R/PR 境界温度は950 $\mathrm{C}$ 加熱

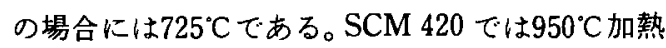
のときR/PR塄界温度は50\%区下に対して $850^{\circ} \mathrm{C}$

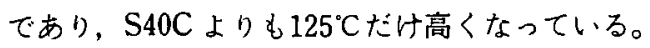
また $1150^{\circ} \mathrm{C}$ 加熱の上きより境界温度は75 $100^{\circ} \mathrm{C}$ たけ低くなっている。

再結晶挙動に対する加熱盜度の影響は初期オー ステナイト粒度とい5因子を通じて作用すると考

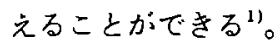

各鋼種の R/PR 境界区延温度を王延前のオ一 ステナイト結晶粒度の関数として整理して Fig. 4 に示す。ここでは，王下率50\%における R/PR 境 界温度をとりあげた。図にはSCM 435 とCM $420+\mathrm{Nb}$ 鋼における結果も並記した。図におい て, 同一の初期オーステナイト粒度，例えば粒度 4 の場合の各鋼種の $\mathrm{R} / \mathrm{PR}$ 境界温度を比較する

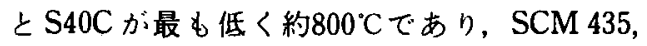
SCM 420 の順に高く, SCM $420+\mathrm{Nb}$ が最も高

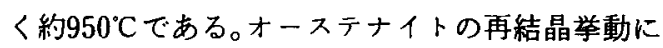
及ほす炭素の影響はほとんどないと考えられるの で2), S40C と SCM 435 および SCM 420 との, R/ $\mathrm{PR}$ 境界温度の差は特にMo 拈よひ $\mathrm{Cr}$ の固溶元 素によってもたらされたものと考皇られる。また $\mathrm{Nb}$ の再結晶抑制効果がこれらの固溶元素の効果 よりも大きいことがわかる。

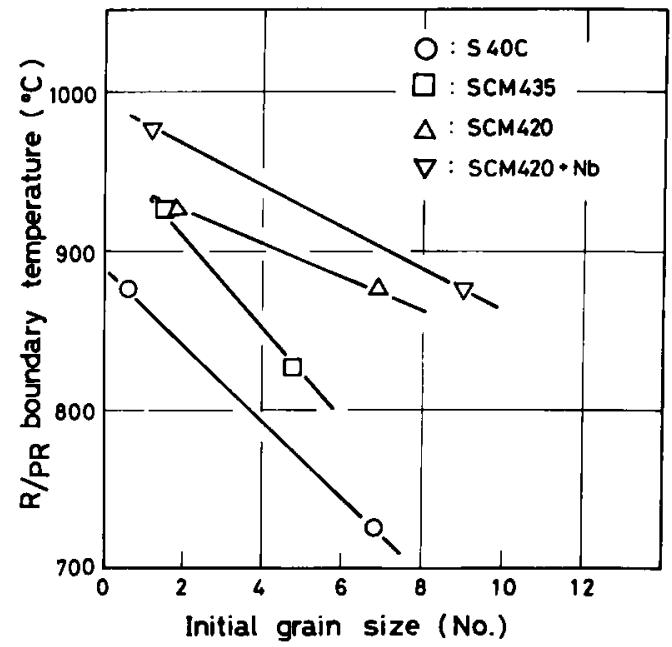

Fig. 4. Effect of initial grain size on the $\mathrm{R} / \mathrm{PR}$ boundary in several steels (reduction $50 \%)$.

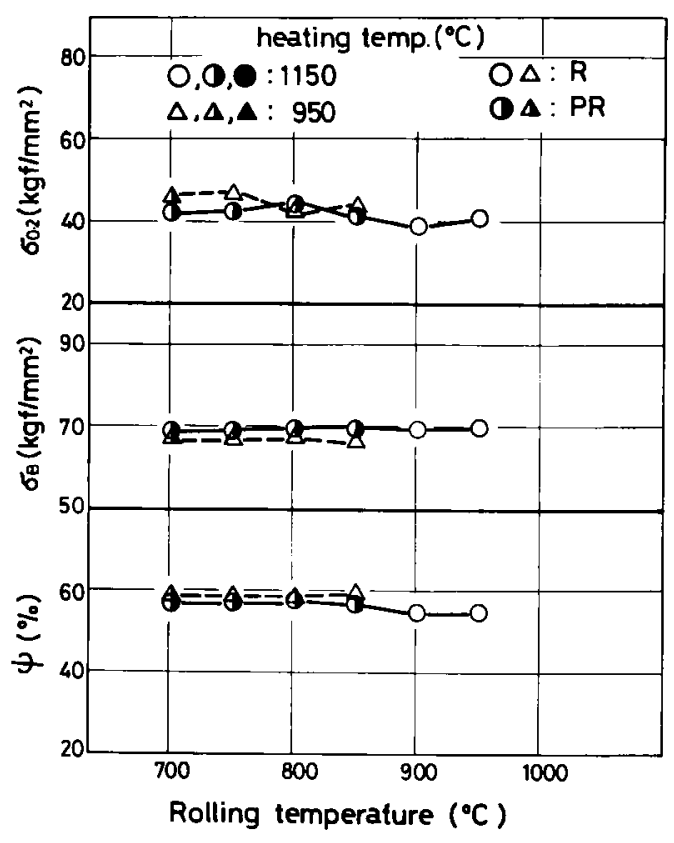

Fig. 5. Effect of rolling temperature on the tensile properties in $\mathrm{S} 40 \mathrm{C}$ (reduction $50 \%)$.

\section{2 機械的性兵に及ほす圧延条件の影需}

1 パスで50\%の王下率を加え板厚 $10 \mathrm{~mm} に し$ た後空冷した試料の機械的性質に及ほすす王延前加 熱温度上王延温度の影罊を各鋼種について Fig. 5 〜 8 に示す。S40C(Fig. 5)においては，加熱温度と 王延温度を変化させても機械的性質ははとんど変 
化しないが，SCM 435, SCM 420 およひ SCM $420+\mathrm{Nb}$ 鋼においてては加熱温度および王延温度 に複雜に依存している。すなわち， $1150^{\circ} \mathrm{C}$ 加熱の

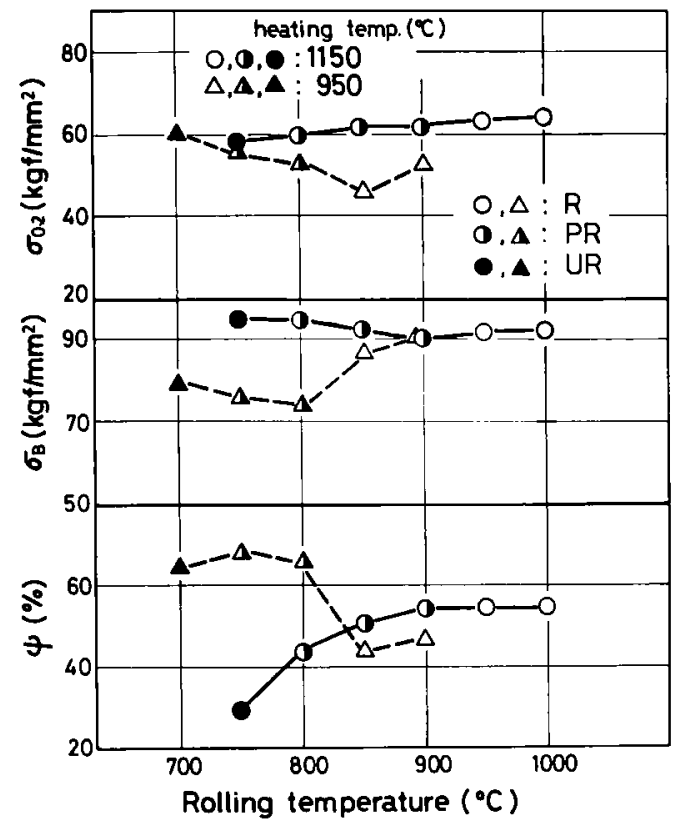

Fig. 6. Effect of rolling temperature on the tensile properties in SCM435 (reduction $50 \%$ ).

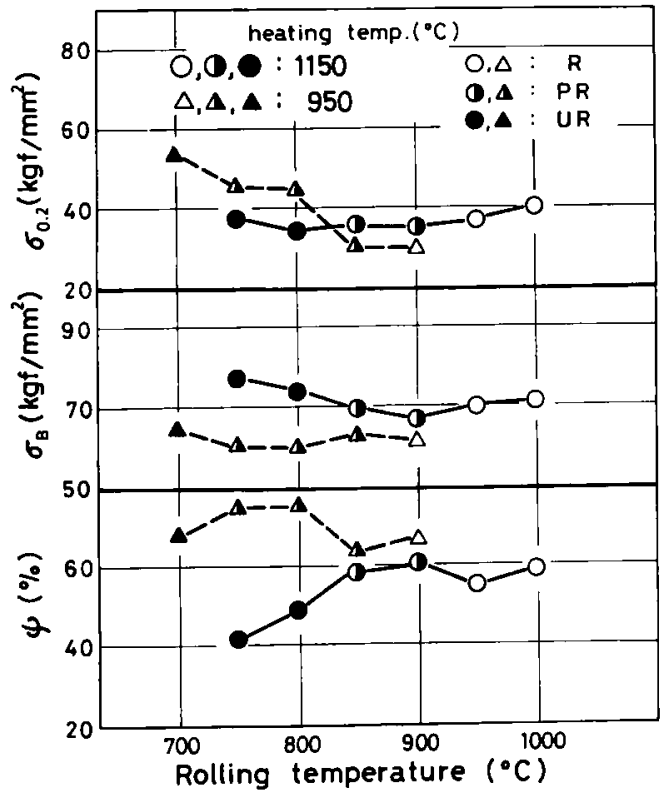

Fig. 7. Effect of rolling temperature on the tensile properties in SCM420 (reduction $50 \%$ ).
場合には，壬延温度の低下に伴い。. $0.2 \%$ 耐力と絞り は低下し，逆に引張り強さは少し高くなる。しか し $950^{\circ} \mathrm{C}$ 加熱の場合には, $1150^{\circ} \mathrm{C}$ 加熱の場合とは逆 に，代延温度が低下すると0.2\%耐力と絞りは高く なり，引張り強さは下がる。伸びの変化は校りと 同し傾向を示寸。正延後空冷した試料の代表的 : クロ組織をPhoto. 1 に S40C および SCM $435 に$ ついて, Photo. 2 に SCM 420 おょよひ SCM $420+$ $\mathrm{Nb}$ 鋼について示す。S40Cでは,いずれの場合もフ ェライトとパーライトの組織である。SCM 420 お よびSCM $420+\mathrm{Nb}$ 銅に扰いては,皎りが著しく 向上した压延温度に対するミク口組織はフェライ トとパーライトから成り，それ以外の場合はべイ ナイトおよび少量のマルテンサイトの硬化組織が 共存していた。また引張り試験に批いて、これら の硬化組織が存在する場合には降伏点がなく, 一 方フェライトとハーライトのみの場合には，いず れの鋼種においても降伏点が認められた。

\section{3 冷却变態特性に及ほす等間加工条件の 影䇾}

鋼のオーステナイト粒度が変態特性に大きく影 響することはよく知られている3，4)。3.1では再結 晶の有無と熱間加工条件との関係を調べた。ここ

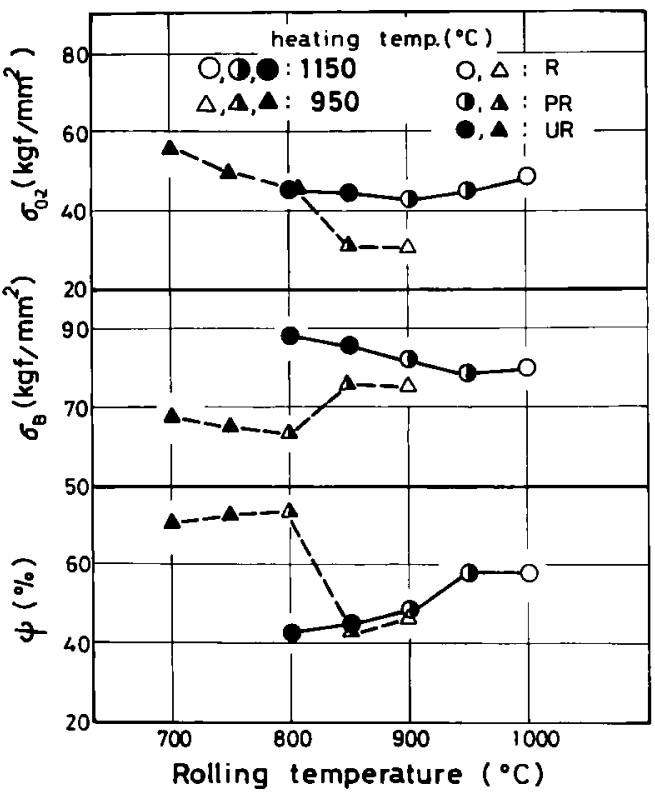

Fig. 8. Effect of rolling temperature on the tensile properties in $\mathrm{SCM} 420+\mathrm{Nb}$ (reduction 50\%). 


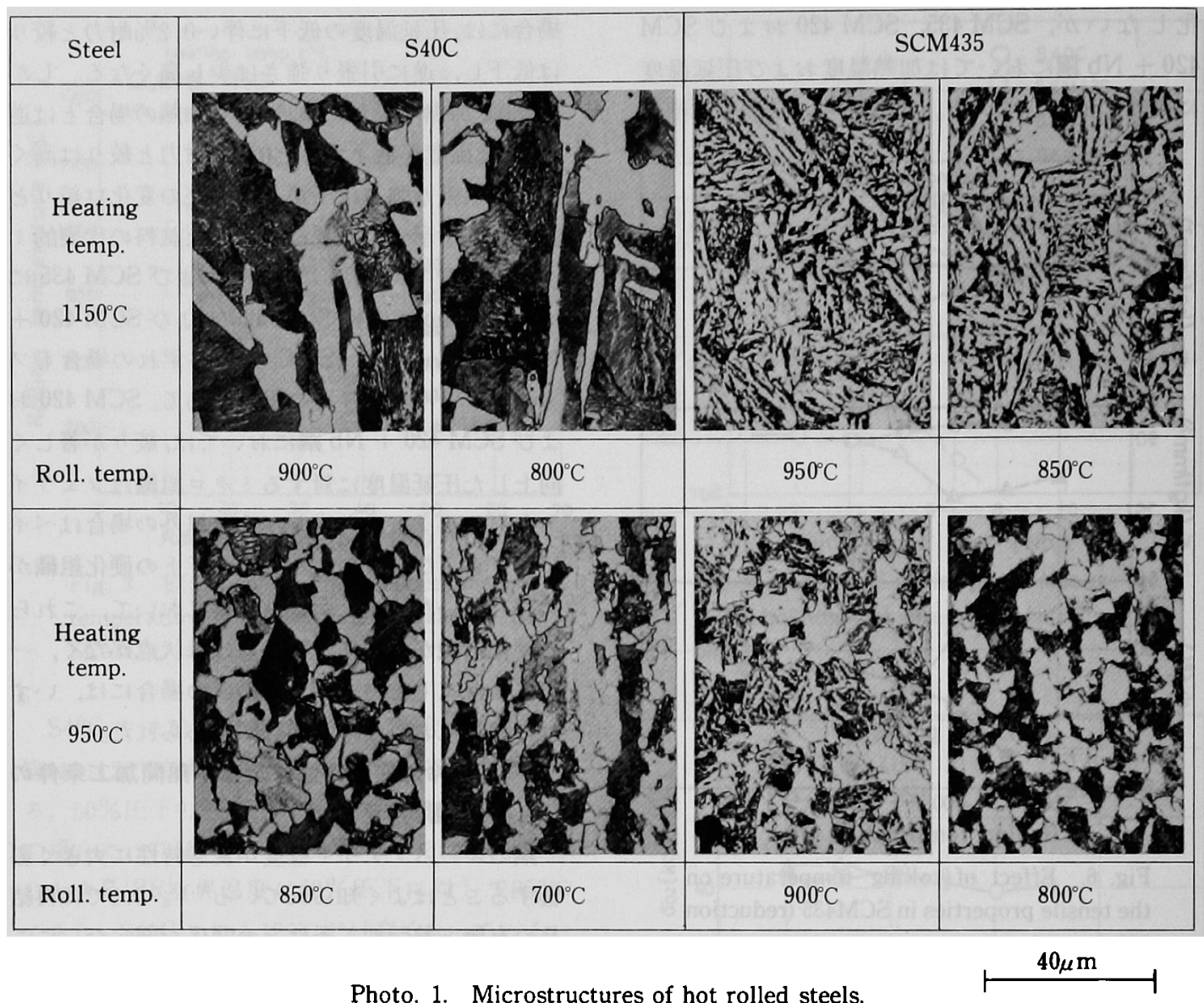

では再結晶粒度を問題にとりあげこの粒度がど のよらに压延後の変態挙動に影晦しているかを考 えたい。

熱間圧延後の急冷で再結晶が認められた領域 ( $\mathrm{R}$ 領域) では，その再結晶粒度は正延温度には あまり支配されないが压延の初期加熱温度には強 く依存する。すなわち，熱間加工前の粒度の影晦 を強く受ける。SCM 435 において圧下率が50\%の 場合, $1150^{\circ} \mathrm{C}$ 加熱時の初期粒度 1.5 力ら R R 領域では 5.8 の粒度に再結晶し， $950^{\circ} \mathrm{C}$ 加熱時の初期粒度 4.8 から R 領域で 9.5 の粒度に再結晶する。このよう に再結晶粒度は初期加熱温度によって大きく变っ ている。

通常の連続冷却变態に及ぼすオーステナイト粒 度の影響をSCM 435 について調べてみた。変態 前の粒度を変えるために, $1150^{\circ} \mathrm{C}$ およひ $850^{\circ} \mathrm{C} に$ 加

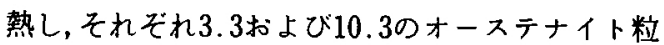

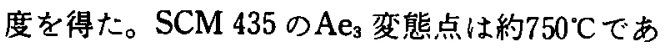

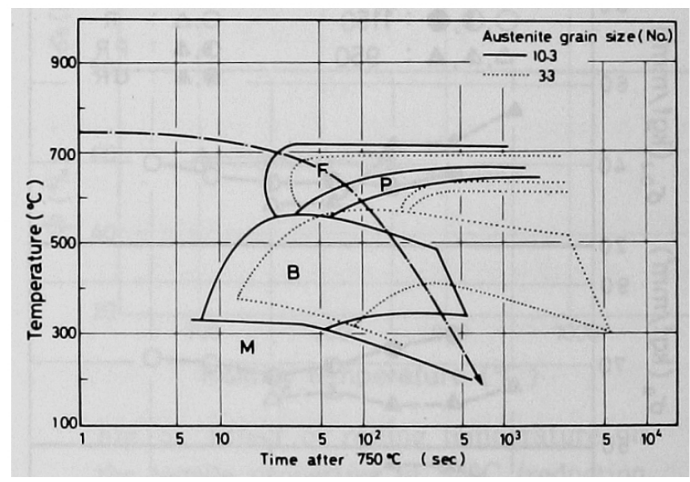

Fig. 9. Effect of austenite grain size on the CCT curves upon reheating in SCM435.

るので $750^{\circ} \mathrm{C}$ 以下の経過時間を横軸にとって連続 冷却变態曲線を求めた結果を Fig. 9 亿示す。同図 に示す冷却曲線は压延実験材の空冷に対するもの である。同図よりオーステナイト結晶粒が微細に なるとフェライト，ハーライト変態開始曲線は高 


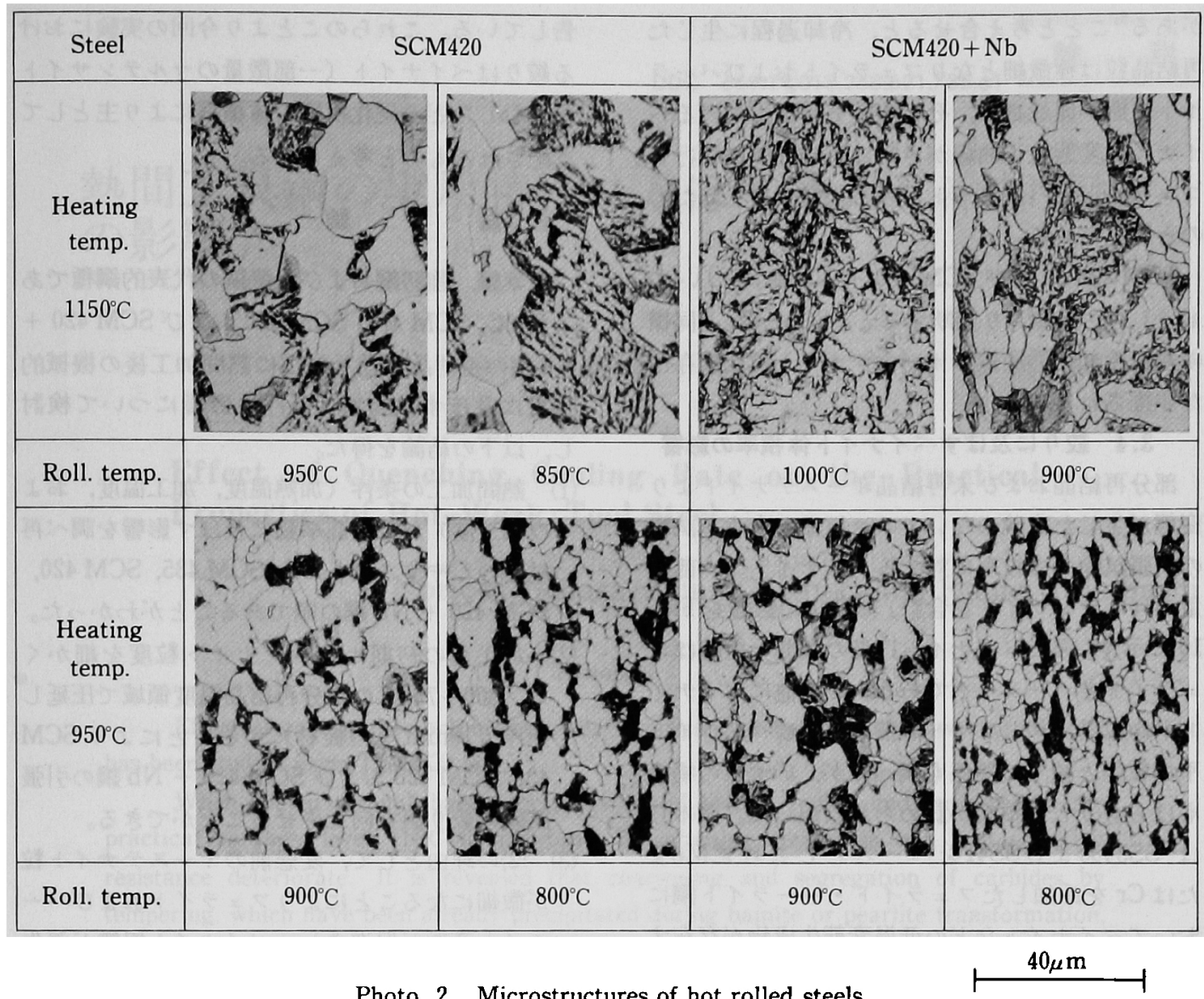

温および短時間側に移行し，さらにべイナイト変 態開始曲線子短時間側に移行することがわかる。 これを厚さ $10 \mathrm{~mm}$ の圧延実験試片の冷却曲線と 対比してみると，変態前のオーステナイト結唱粒 が微細になるとパーライト組織がでやすくなると ともにべイナイト量が少なくなることが予想され る。また, Photo. 1 に示したSCM 435 の再結晶域 で圧延後空冷した場合のミク口組織は压延後の才 ーステナイト粒度が5.8（1150 $\mathrm{C}$ 加熱950 C压延） の時にはフェライトとべイナイトであり，一方 9.5 (950'C 加熱 $900^{\circ} \mathrm{C}$ 压延）の場合にはフェライト， パーライト拉よびペイナイトの混在した組織であ ク,Fig. 9 の結果と対応する。このように再結晶域 王延後の ミク口組穖は通常の連続冷却变態曲線 （再加熱による）のオーステナイト粒度依存性に より，説明することができる。

つぎに部分再結晶領域で加エした時の SCM 435 のミクロ組織の変化について考察する。 $1150^{\circ} \mathrm{C} て ゙$ 加熱後 $850^{\circ} \mathrm{C}$ の部分再結晶温度で压延し た時のミク口組織は粗大なべイナイトと比較的微 細なフェライトが混在しているが, $950^{\circ} \mathrm{C} て ゙$ 加熱後 $800^{\circ} \mathrm{C}$ 部分再結晶温度で圧延した時のミク口組 織は均一微細なフェライトとパーライト組織であ る。また $1150^{\circ} \mathrm{C}$ 加熱の場合には末再結晶オーステ ナイトから変態が生じた痕跡が認められるが, $950^{\circ}$ C 加熱ではそのような痕跡は認められず再結 晶オーステナイト粒から変態が生じたものと考え られる。すなわら加工前のオーステナイト粒が粗 大な場合には部分再結晶域で加工されて生した末 再結晶オーステナイトは加工後の変態に至る冷却 過程でほとんど再結晶が進行せず，他方加工前の オーステナイト粒が微細な場合には部分再結晶域 で加工されて生じた未再結晶オーステナイトは加 工後変態に至る冷却過程で再結晶が進行したこと を物語るものである。また压延温度が低下するに 従って再結晶オーステナイト粒が徽細になる傾向 
がある゙ことと考え合せると，冷却過程に生じた 再結晶粒は極微細となりフェライトおよびパーラ イト変態が促進され，その結果 Fig. 9 におけるへ イナイト变態完了曲線がさらに短時間側に移行し フェライトとパーライトのみの組織が得られたも のと考えられる。

SCM 420 およびSCM $420+\mathrm{Nb}$ 鋼について も：ミクロ組織より判断すると， SCM 435 と同様 の連続冷却变態曲線のオーステナイト粒度依存性 が類推される。

\section{4 絞クに及ほすべイナイト体積率の影留}

部分再結晶扰よび未再結晶オーステナイトより 変態が生じた痕跡のない:ク口組織を有する試料 の引張試験での絞りに対するぺイナイト（一部政 量のマルテンサイトを含む）体積率の影響を Fig. 10 に示す。図でべイナイト以外の残部の組織はフ ェライトとパーライトである。この他にべイナイ ト平均粒径, フェライト体積率拈よびフェライト 平均粒径と皎りの関係も調べたが，いすれれの場合 もはっきりした傾向が認められなかった。荒木ら は蛙SS34およびS41をべースとしこれにMoま たはCrを添加したフェライト・パーライト鋼に おいてベイナイトなとの低温変態生成物が存在す る場合に絞りが Fig. 10 と同様の傾向を示すこと を見い出している。また岡林らばクヘイナイトと マルテンサイトの二相混合組織よりなる $0.42 \%$ $\mathrm{C}-\mathrm{Ni}-\mathrm{Cr}-\mathrm{Mo}$ 鋼においてもマルテンサイト体積 率と絞りの関係が図と同様の傾向を示すことを報

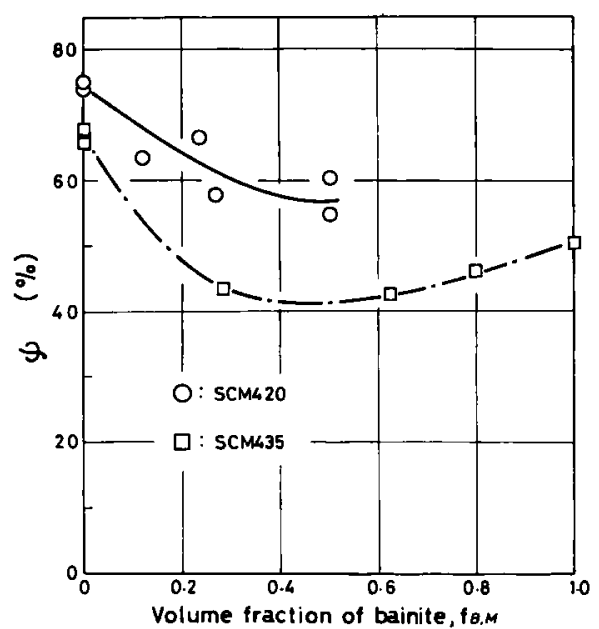

Fig. 10. Relation between reduction of area and volume fraction of bainite in SCM420 and SCM435.
告している。これらのことより今回の実験におけ る校りはベイナイト（一部微量のマルテンサイト を含む）などの硬化組織の体積率により主として 支配されるむのと考えられる。

\section{4. 結論}

炭素鋼，強靶鋼および肌焼鋼の代表的鋼種であ る S40C, SCM 435, SCM 420 扎よひ SCM $420+$ $\mathrm{Nb}$ 鋼の再結晶挙動ならびに熱間加工後の機械的 性質に及ぼす熱間加工条件の影響について検討 し, 以下の結論を得た。

（1） 熱間加工の条件（加熱温度，加工温度，およ び加工度）が再結晶举動に及住す影響を調べ再 結晶のしやすさは S40C, SCM 435, SCM 420 , $\mathrm{SCM} 420+\mathrm{Nb}$ 鋼の順であることがわかった。

(2) 加工前の初期オーステナイト粒度を細かく し，800 750 $\mathrm{C}$ の部分再結晶温度領域で王延し 空冷 (10mm 厚の板材) することにより SCM 435, SCM 420 および SCM $420+\mathrm{Nb}$ 鋼の引張 試験の絞り值を向上させることができる。

（3）（2の理由として，変態前のオーステナイト粒 が微細になることによりフェライトおよびハー ライト変態が促進され，ベイナイト組織が消失 したことによると考えた。さらに引張り試験に おいてこれらの硬化組織が存在しない場合に は降伏点が認めら机る。

\section{（文 献）}

1) 田中：鉄鋼基礎共同研究会高温変形部会シン ボジウム，(1979)， 55

2) 井上：鉄鋼基礎共同研究会高温変形部会シン ポジウム, (1980), 102

3) 町田, 勝, 暒：鉄之鋼，66（1980）4, S 597

4) C.M. Sellars and J.A. Whiteman : Metal Science, (1979), 187

5 ) I.Kozasu, C.Ouchi, T.Sampei and T.Okita : Proceedings of Microalloying '75, Union Carbide Corp., New York, (1975), 120

6)青木, 金尾, 荒木：鉄と鋼，54（1968）4，433

7) 富田, 宮本, 岡林：鉄と鋼, 64 (1978) 9, 1379 